\title{
Renal Osteodystrophy in Children Undergoing Continuous Ambulatory Peritoneal Dialysis
}

\author{
LUC PAUNIER, ${ }^{(32)}$ ISIDRO B. SALUSKY, EDUARDO SLATOPOLSKY, HOOSHANG KANGARLOO, \\ JOEL D. KOPPLE, RONALD L. HORST, JACK W. COBURN, AND RICHARD N. FINE \\ Department of Pediatrics, Division of Pediatric Nephrology [L.P., I.B.S., R.N.F.], Department of Radiology, \\ Division of Pediatric Radiology [H.K.] and Department of Medicine [R.L.H.], University of California, Los \\ Angeles, School of Medicine, Los Angeles, California, USA, The Renal Division, Washington University School \\ of Medicine, St. Louis, Missouri, USA [E.S.], Department of Medicine, Division of Nephrology, Harbor-UCLA \\ Medical Center [J.D.K.] and Medical and Research Services, Veterans Administration Wadsworth Medical \\ Center [J.W.C.], Los Angeles, California, USA, and National Animal Disease Center, Ames, Iowa, USA [R.L.H.]
}

\begin{abstract}
Summary
This paper describes a retrospective evaluation of the course of renal bone disease in 14 children undergoing treatment with continuous ambulatory peritoneal dialysis (CAPD) for an average of 11.9 \pm 1.5 months (mean $\pm \mathrm{SE}$ ). The patients were divided in two groups according to the changes in serum alkaline phosphatase activity during the period of observation: five patients had alkaline phosphatase activity that decreased or was relatively stable (group I), and nine patients exhibited a rising serum alkaline phosphatase activity (group II). Serial radiological examinations showed adequate control of renal osteodystrophy in the patients of group I, whereas the patients of group II had no improvement or worsening of their bone disease. Group I had higher serum calcium and lower parathyroid hormone levels than group II at the end of period of observation despite similar dosage of vitamin $D$ metabolite. The progression of bone disease was not related to the duration of CAPD or type of previous treatment for end stage renal disease.

The observation that the radiological manifestations of secondary hyperparathyroidism were prevented in patients whose serum calcium levels were frequently above $2.62 \mathrm{mmol} / \mathrm{liter}$ (group I) while serum calcium levels between 2.25 and $2.50 \mathrm{mmol} / \mathrm{liter}$ in group II patients failed to lead to regression of secondary hyperparathyroidism is consistent with the existence of altered "setpoint" regulation of the parathyroid gland in children undergoing CAPD.
\end{abstract}

\section{Abbreviations}

CAPD, continuous ambulatory peritoneal dialysis ESRD, end stage renal disease iPTH, immunoreactive parathyroid hormone 25-OHD, 25-hydroxyvitamin D DHT, dihydrotachysterol

CAPD has recently been introduced for the treatment of children with ESRD $(2,3)$. Presently, increasing numbers of children are undergoing treatment with this procedure because of certain advantages over hemodialysis or intermittent peritoneal dialysis; these advantages include better subjective acceptance by both the patients and their parents, decreased need for dietary and fluid restriction, and improved control of hypertension $(2,3,14,17,19,26,27)$. The long-term effects of CAPD on the course of renal bone disease in children with ESRD are unknown. This report describes a retrospective evaluation of the course of renal osteodystrophy in 14 pediatric patients treated with CAPD for an average of $11.9 \pm 1.5$ months (SE).

\section{MATERIALS AND METHODS}

Fourteen patients, eight males and six females, who were treated with CAPD for 6-21 months were evaluated (Table 1). Five patients had been treated with CAPD following rejection of a kidney transplant; these patients were previously treated with hemodialysis and/or intermittent peritoneal dialysis for 1 to 21 months. One patient received prior treatment with intermittent peritoneal dialysis only. CAPD was the initial treatment modality for ESRD in eight patients (Table 1). Three patients had undergone parathyroidectomy 4,2 , and 3 years before the initiation of CAPD (patients 2, 8, and 9, respectively).

All patients were dialyzed through an indwelling Tenckhoff catheter, according to the method modified from Oreopoulos $(24,26)$. Each patient received 4-5 exchanges/day, 0.5 to 2 liters/ exchange for 7 days/week. The dialysate solution (Dianeal, Travenol Laboratories) contained sodium (132 meq/liter), calcium (3.5 meq/liter), magnesium (1.5 meq/liter), chloride (102 meq/ liter), lactate ( $35 \mathrm{meq} / \mathrm{liter}$ ), and was available with three different glucose concentrations: $1.5,2.5$, and $4.25 \%$. The patients or their parents were instructed to use a solution with the glucose concentrations adjusted to the patient's need for the ultrafiltration, i.e. state of hydration, weight, and blood pressure.

Upon initiation of the CAPD treatment program, all patients received treatment with small doses of either calcitriol or dihydrotachysterol. Eleven patients received calcitriol (Rocaltrol, Hoffmann LaRoche) at a dosage of $0.25-0.5 \mu \mathrm{g} /$ day $(5-36 \mathrm{ng} /$ $\mathrm{kg} /$ day), and three patients received dihydrotachysterol at a daily dose of $0.125-0.250 \mathrm{mg} /$ day $(4-23 \mu \mathrm{g} / \mathrm{kg} /$ day). The dosage was adjusted to maintain the serum calcium level between 2.25 and $2.62 \mathrm{mmol} / \mathrm{liter}$.

Each patient received a preparation of aluminum hydroxide to bind intestinal phosphate. The dosage was varied and was frequently adjusted during the course of CAPD to maintain a serum phosphorus level below $1.77 \mathrm{mmol} /$ liter. Dietary energy, protein, and calcium intake were evaluated once monthly at each clinic visit throughout the treatment period. Intake was quantitated using 3-day dietetic diaries and a dietetic interview by the same pediatric renal dietitian with a 3-day weighed technique. The patients were seen at monthly intervals and routine serum biochemical analyses including creatinine, urea nitrogen, electrolytes, calcium, phosphorus, and alkaline phosphatase activity were measured using standard clinical laboratory techniques. The normal range of alkaline phosphatase activity in children 
Table 1. Clinical features of patients treated with CAPD

\begin{tabular}{|c|c|c|c|c|c|}
\hline \multirow{2}{*}{$\begin{array}{l}\text { Patient } \\
\text { No. }\end{array}$} & \multirow{2}{*}{$\begin{array}{l}\text { Age at } \\
\text { onset of } \\
\text { CAPD } \\
\text { (years) }\end{array}$} & \multirow{2}{*}{ Sex } & \multirow[b]{2}{*}{ Primary disease } & \multicolumn{2}{|c|}{$\begin{array}{l}\text { Duration of treatment } \\
\text { of ESRD (months) }\end{array}$} \\
\hline & & & & HD-IP-TP* & CAPD \\
\hline 1 & 1.5 & $\mathrm{~F}$ & Acute tubular necrosis & $0-3-0$ & 15 \\
\hline 2 & 7.0 & $\mathrm{~F}$ & Dysplastic kidneys & 0 & 7 \\
\hline 3 & 10.4 & $\mathrm{~F}$ & Focal glomerulosclerosis & $18-0-4$ & 9 \\
\hline 4 & 15.0 & F & Dysplastic kidneys & 0 & 6 \\
\hline 5 & 10.0 & $\mathbf{M}$ & Dysplastic kidneys & 0 & 6 \\
\hline 6 & 11.3 & & Glomerulonephritis & $21-3-7$ & 19 \\
\hline 7 & 9.6 & F & Polycystic kidneys & 0 & 21 \\
\hline 8 & 14.2 & $\mathrm{~F}$ & Hemolytic uremic syndrome & $15-0-10$ & 19 \\
\hline 9 & 9.6 & & Dysplastic kidneys & $3-16-89$ & 19 \\
\hline 10 & 8.9 & & Focal glomerulosclerosis & $2-1-24$ & 12 \\
\hline 11 & 1.6 & & Dysplastic kidneys & 0 & 10 \\
\hline 12 & 4.0 & & Dysplastic kidneys & 0 & 7 \\
\hline 13 & 10.9 & & Dysplastic kidneys & 0 & 11 \\
\hline 14 & 5.6 & & Focal glomerulosclerosis & 0 & 6 \\
\hline
\end{tabular}

* Refers to duration of treatment for ESRD prior to CAPD: HD, hemodialysis; IP, intermittent peritoneal dialysis; TP, transplant.

according to age and sex was obtained from the data of Cherian and Hill (10). At the end of the observation period, iPTH and 25-OHD levels were evaluated. Serum iPTH was determined by radioimmunoassay, according to methods reported elsewhere and using an antiserum which reacts to the midportion of $\mathrm{C}$ terminal fragment (antibody chicken 9) (22). The serum 25OHD levels were measured by the direct UV absorbance after high pressure liquid chromatography (21). Control values have been previously published (15).

Radiological examination of the left hand and wrist and an anterior-posterior view of both knees were obtained at 6-month intervals using a standardized radiological technique. On completion of the observation period, the radiographs were analyzed by three independent reviewers and were evaluated according to the presence of radiological signs of both growth zone lesions and erosions of secondary hyperparathyroidism. The following scoring system was used: 0 , normal; 1 , signs barely visible; 2 , moderate; and 3, severe alterations. The presence of an abnormal trabecular pattern was given the score of 1 . The sums of the scores of the three reviewers were averaged. Radiographs with the most severe osteodystrophy would be rated 7 (growth zone lesion 3, subperiosteal erosions 3, and abnormal trabecular pattern 1) while normal radiographs would receive a score of 0 .

The effluent spent dialysate was collected over the 48 -h period preceding a clinic visit and refrigerated. The total outflow volume was measured, and calcium, magnesium, and phosphorus concentrations were determined in the outflow fluid as well as in samples from the same lot of unused dialysate. Net peritoneal mass transfer of solutes was calculated for each 24 hour period as follows: mass transfer $=$ (inflow dialysate concentration $\times$ inflow volume) - (outflow dialysate concentration $\times$ volume drained). The mass transfer characteristics were determined on 39 occasions in 12 patients.

Grouping of Patients and Statistical Analysis. On the basis of clinical assessment and biochemical data, it was apparent that there was variability in the course of renal osteodystrophy in these patients. Moreover, the radiographic features appeared to parallel the changes in the serum alkaline phosphatase activity. Therefore, the patients were divided into two groups: five patients with falling or relatively stable alkaline phosphatase activity (change $<30 \%$ ) were assigned to group I; nine patients who exhibited a rising serum alkaline phosphatase activity (change $>$ $30 \%$ ) were assigned to group II (Fig. 1). In Tables 1 and 3, patients in group I are cases 1-5 and those in group II are cases 6-14. Means between the groups were compared using Student's unpaired $t$ test. Values are reported as mean \pm SE.

\section{RESULTS}

The data in Table 2 show the total mean values and ranges for serum creatinine, urea nitrogen, carbon dioxide content, and total protein levels in the 14 patients during the period of CAPD. No patient had significant metabolic acidosis, and there were no differences between group I and group II. The mean daily dialysate glucose concentration during the period of observation was $2.25 \pm 0.53 \mathrm{~g} / \mathrm{dl}$ in group I and $1.90 \pm 0.16 \mathrm{~g} / \mathrm{dl}$ in group II. The mean energy intake was $68 \pm 6.0 \mathrm{kcal} / \mathrm{kg} /$ day corresponding to $79 \pm 3.7 \%$ of the recommended daily allowances adjusted according to height/age and sex. Mean protein intake was $2.4 \pm$ $0.2 \mathrm{~g} / \mathrm{kg} /$ day, representing $94 \pm 6.7 \%$ of that prescribed (28).

Table 3 shows the initial and final serum calcium levels, the overall mean of serum calcium and phosphorus levels, the initial and final alkaline phosphatase activities, the final serum 25 OHD levels, the initial and final radiological scores, the average dosage of calcitriol or DHT, and the mean dietary calcium and aluminum hydroxide intake for each individual patient. The mean serum calcium levels were not different between groups I and II at the initiation of CAPD. By contrast, the serum calcium levels were significantly higher in group I at the end of the study. The mean serum phosphorus levels were not different in the two groups. Also, the serum alkaline phosphatase activity was not different in the two groups at the onset of CAPD, but the patients in group II had significantly higher levels at the end of the observation period. At the initiation of the study, the values of alkaline phosphatase activity in two of five patients in group I and in seven of nine in group II were within the 95 th percentile

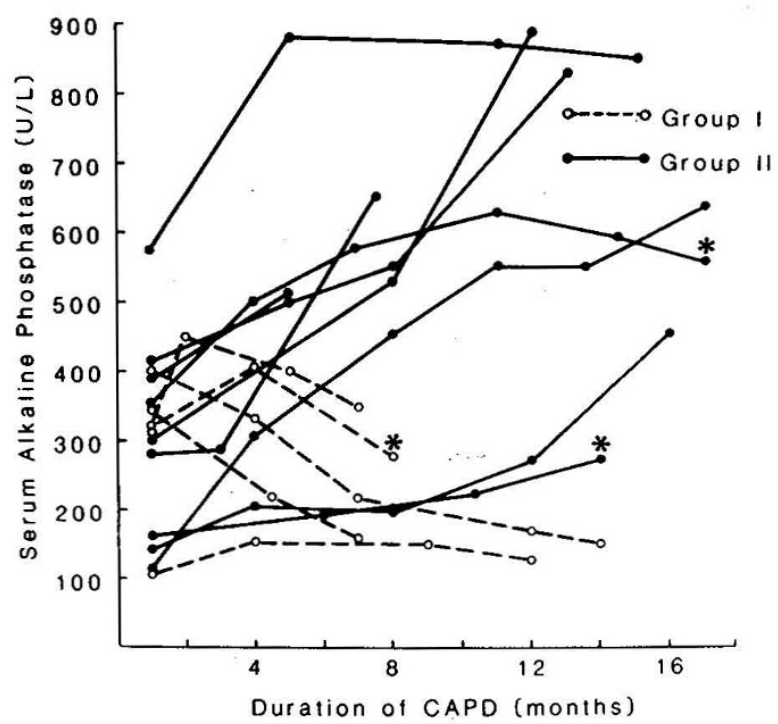

Fig. 1. Evolution of the serum alkaline phosphatase activity during CAPD. The patients were separated into two groups; group I (---) serum alkaline phosphatase activity not raised and group II (-) serum alkaline phosphatase activity raised during the period of observation. *, patients requiring parathyroidectomy prior to CAPD (see "Materials and Methods").

Table 2. Serum biochemical parameters during CAPD

\begin{tabular}{lcc}
\hline & Total mean* $\pm \mathrm{SE}$ & $\begin{array}{c}\text { Range of individual } \\
\text { patient mean values }\end{array}$ \\
\hline Creatinine $(\mathrm{mg} / \mathrm{dl})$ & $8.3 \pm 0.8$ & $4.5-13.8$ \\
Urea nitrogen $(\mathrm{mg} / \mathrm{dl})$ & $73 \pm 4$ & $46-101$ \\
$\mathrm{HCO}_{3}(\mathrm{meq} / \mathrm{liter})$ & $22.5 \pm 0.6$ & $18.2-24.6$ \\
Total protein $(\mathrm{g} / \mathrm{dl})$ & $6.0 \pm 0.1$ & $5.0-6.6$ \\
\hline
\end{tabular}

* This represents the total mean of individual mean values which were calculated using all the observations made in each individual patient during treatment with CAPD. 
Table 3. Values of serum calcium, phosphorus, alkaline phosphatase and 25-OHD levels and evolution of the radiological score of bone disease: dosage of calcitriol (or DHT), calcium, and aluminum intake in children treated with CAPD

\begin{tabular}{|c|c|c|c|c|c|c|c|c|c|c|c|c|c|c|c|}
\hline \multirow[b]{2}{*}{$\begin{array}{l}\text { Patient } \\
\text { No. }\end{array}$} & \multicolumn{3}{|c|}{$\begin{array}{c}\mathrm{Ca} \\
(\mathrm{mmol} / \mathrm{liter})\end{array}$} & \multirow[b]{2}{*}{$\begin{array}{c}\mathrm{P}^{*} \\
\text { (mmol/liter) }\end{array}$} & \multicolumn{2}{|c|}{$\begin{array}{c}\text { Alkaline } \\
\text { phosphatase } \\
(\mu \mathrm{g} / \text { liter })\end{array}$} & \multicolumn{3}{|c|}{$\begin{array}{l}25-\mathrm{OHD} \\
(\mathrm{ng} / \mathrm{ml})\end{array}$} & \multicolumn{2}{|c|}{$\begin{array}{l}\text { Bone disease } \\
\text { radiological score }\end{array}$} & \multicolumn{2}{|c|}{$\begin{array}{l}\text { Calcitriol } \\
\text { dosage }\end{array}$} & \multicolumn{2}{|c|}{$\begin{array}{c}\mathrm{Ca} \text { and } \mathrm{Al} \text { intake } \\
\text { (mg/day) }\end{array}$} \\
\hline & $\begin{array}{l}\text { Onset of } \\
\text { CAPD }\end{array}$ & Mean & $\begin{array}{l}\text { End of } \\
\text { study }\end{array}$ & & $\begin{array}{l}\text { Onset of } \\
\text { CAPD }\end{array}$ & $\begin{array}{l}\text { End of } \\
\text { study }\end{array}$ & $\mathrm{D}_{2}$ & $\mathrm{D}_{3}$ & Total & $\begin{array}{c}\text { Onset of } \\
\text { CAPD }\end{array}$ & $\begin{array}{c}\text { Final } \\
\text { observation }\end{array}$ & $\mu \mathrm{g} /$ day & $\mathrm{ng} / \mathrm{kg} /$ day & $\mathrm{Ca}$ & $\mathrm{Al}$ \\
\hline \multicolumn{16}{|l|}{ Group I } \\
\hline 1 & 2.50 & 2.52 & 3.0 & 1.52 & 400 & 153 & 26.8 & 5.1 & 31.9 & 2 & 0.7 & (DHT $0.250 \mathrm{mg} /$ day) & $(73 \mu \mathrm{g} / \mathrm{kg} /$ day $)$ & 440 & 880 \\
\hline 2 & 2.52 & 2.65 & 2.90 & 2.07 & 322 & 282 & 10.7 & 23.9 & 34.6 & 3 & 2.3 & 0.50 & 36 & 1020 & 1557 \\
\hline 3 & 3.05 & 3.02 & 3.02 & 1.87 & 119 & 151 & 2.2 & 31.3 & 33.5 & 3 & 3 & 0.125 & 5 & 400 & 1320 \\
\hline 4 & 2.35 & 2.60 & 2.90 & 1.81 & 340 & 99 & & & & 2 & 2 & 0.50 & 15 & 1020 & 2076 \\
\hline 5 & 2.25 & 2.48 & 2.63 & 1.62 & 452 & 346 & 4.0 & 3.7 & 7.7 & 5 & 3.7 & 0.25 & 8 & 580 & 2595 \\
\hline Mean & 2.53 & 2.60 & 2.90 & 1.78 & 326 & 206 & 10.9 & 16.0 & 26.9 & 3.0 & 2.3 & & & 692 & 1686 \\
\hline SEM & 0.15 & 0.13 & 0.08 & 0.23 & 63 & 46 & 5.6 & 6.9 & 6.4 & 0.6 & 0.5 & & & 138 & 299 \\
\hline \multicolumn{16}{|l|}{ Group II } \\
\hline 6 & 2.68 & 2.43 & 2.40 & 1.49 & 113 & 640 & 2.1 & 25.6 & 27.7 & 3 & 4.3 & 0.50 & 14 & 670 & 1384 \\
\hline 7 & 2.70 & 2.73 & 2.63 & 1.94 & 142 & 463 & 3.1 & 33.2 & 36.3 & 2.3 & 3 & 0.125 & 5 & 750 & 2768 \\
\hline 8 & 2.70 & 2.65 & 2.48 & 1.55 & 161 & 270 & 8.4 & 18.2 & 26.6 & 3 & 3 & (DHT $0.125 \mathrm{mg} /$ day) & $(4 \mu \mathrm{g} / \mathrm{kg} / \mathrm{day})$ & 714 & 1557 \\
\hline 9 & 2.33 & 2.45 & 2.55 & 1.36 & 350 & 555 & 4.6 & 21.4 & 26.0 & 4 & 4 & 0.25 & 9 & 990 & 1760 \\
\hline 10 & 2.35 & 2.35 & 2.33 & 1.42 & 350 & 995 & 10.5 & 7.9 & 18.4 & 3 & 6 & 0.50 & 25 & 860 & 1480 \\
\hline 11 & 2.68 & 2.43 & 2.30 & 1.62 & 417 & 855 & 5.3 & 35.1 & 40.4 & 6.3 & 6 & 0.25 & 30 & 116 & 2484 \\
\hline 12 & 2.43 & 2.43 & 2.63 & 2.10 & 286 & 651 & 10.3 & 18.1 & 28.4 & 4.3 & 4.3 & 0.25 & 23 & 780 & 2484 \\
\hline 13 & 2.45 & 2.38 & 2.45 & 1.94 & 305 & 1060 & & & & 3 & 3 & 0.25 & 7 & 540 & 2120 \\
\hline 14 & 2.08 & 1.98 & 1.85 & 1.58 & 371 & 508 & 22.5 & 11.4 & 33.9 & 4 & 3 & (DHT $0.25 \mathrm{mg} /$ day) & $(17 \mu \mathrm{g} / \mathrm{kg} /$ day $)$ & 555 & 1038 \\
\hline Mean & 2.48 & 2.43 & $2.40 \dagger$ & 1.68 & 277 & $666 \dagger$ & 8.4 & 21.4 & 29.7 & 3.6 & $4.1 \ddagger$ & & & 664 & 1897 \\
\hline SEM & 0.08 & 0.20 & 0.08 & 0.26 & 37 & 86 & 2.3 & 3.4 & 2.4 & 0.4 & 0.4 & & & 83 & 197 \\
\hline
\end{tabular}

* Represents mean values for serum P over period of CAPD.

† Difference between group I and group II, $P<0.01$

$\ddagger$ Difference between group I and group II, $P<0.05$. 
of normal for age and sex (10), while at the end of the observation period, the levels were abnormal in all nine patients of group II, while the values in all five patients of group I were normal (Fig. 2). The serum 25-OHD levels were within normal limits (15) at evaluation and did not differ between groups I and II (Table 3 ).

Serum iPTH levels, measured at the end of the study were 75 $\pm 22 \mu \mathrm{l} \mathrm{eq} / \mathrm{ml}$ in group I and $208 \pm 35 \mu \mathrm{leq} / \mathrm{ml}$ in group II $(P$ $<0.02$ ); moreover, the serum calcium levels, measured at the time of iPTH measurement were $2.77 \pm 0.07$ and $2.33 \pm 0.08$ $\mathrm{mmol} /$ liter $(P<0.01)$, respectively. The relationship between the serum iPTH and calcium levels is shown in Figure 3.

The radiological score of bone disease improved in three and did not change in two patients of group I, whereas in group II, three patients showed radiographic signs of worsening bone disease, five patients demonstrated no significant change, and only one patient exhibited definitive evidence of improvement. Moreover, the mean radiological scores were high, i.e. 4 or greater in three of the four patients in group II who exhibited no change, and the overall mean final score was greater in group II than in group I $(P<0.05)$. There was no difference between the score of the groups at the onset of CAPD. The dosage of calcitriol or DHT varied greatly between individual patients, but there was no difference in dosage between the two groups, or in the amount

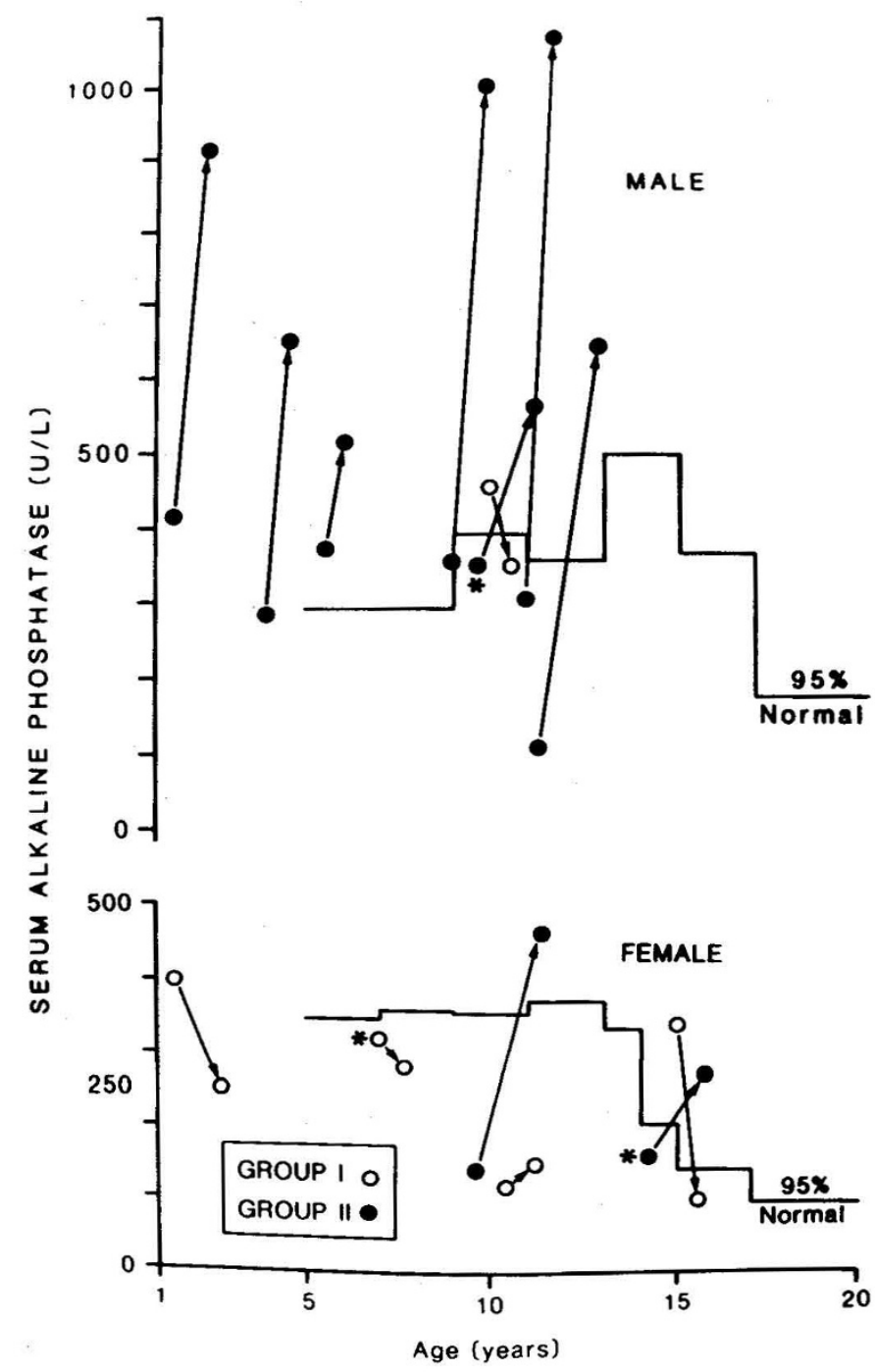

Fig. 2. Evolution of serum alkaline phosphatase activity since initiation of CAPD compared to normal values at the 95 th percentile according to age and sex (8). Values markedly increased in group II. *, patients requiring parathyroidectomy prior to CAPD.

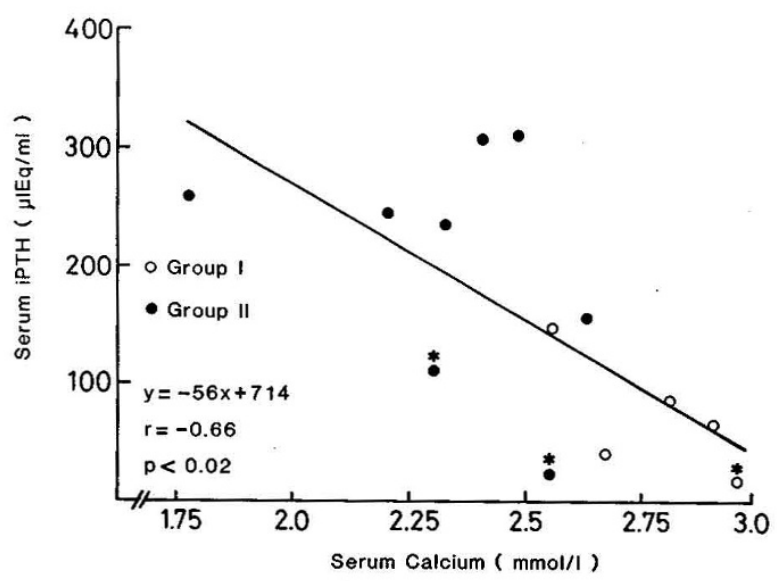

Fig. 3. Relationship between serum iPTH and calcium levels measured at the same time at the end of the period of observation. Patients in group I had higher serum calcium and lower iPTH levels than the patients in group II. *, patients requiring parathyroidectomy prior to CAPD.

of aluminum hydroxide ingested by both groups. Calcium intake varied greatly between patients but the mean values were not different in the two groups.

The relationship between the serum iPTH levels and alkaline phosphatase activity obtained simultaneously at the end of the period of observation is shown in Figure 4. There was a significant correlation between the two parameters when the alkaline phosphatase activity was expressed either in absolute terms $(r=$ 0.63 ) or as a percentage of the age- and sex-adjusted upper normal limit $(r=0.67)$. Since the groupings were made on the basis of change in serum alkaline phosphatase, mean alkaline phosphatase was stable (change from initial, $1-28 \pm 18 \%$ ) in group I, whereas the alkaline phosphatase activity increased by $188 \pm$ $49 \%$ in group II.

Peritoneal Mass Transfer of Water, Calcium, and Phosphorus. The volume of dialysate outflow exceeded the inflow volume by $15 \pm 2 \%$. The total mean value for net mass transfer of calcium from the patient into the dialysate was $-8.5 \pm 7.63 \mathrm{mg} / 24 \mathrm{~h}$, with a range of -100 to $+96 \mathrm{mg} / 24 \mathrm{~h}$. The net transfer of calcium was directly correlated with net fluid loss: $r=0.51, P<$ 0.001 . Net phosphorus mass transfer from the patient into dialysate was $-145.8 \pm 9.4 \mathrm{mg} / 24 \mathrm{~h}$, with a range of -267 to -56.4 $\mathrm{mg} / 24 \mathrm{~h}$. Net phosphate transfer showed no correlation with net fluid loss: $r=0.01$ (not significant). The mean rates of transfer of calcium and phosphorus did not differ between the two groups.

\section{DISCUSSION}

In this study, the pediatric patients treated with CAPD and receiving calcitriol or DHT exhibited one of two relatively divergent courses: some patients showed either stabilization or lack of progression of renal osteodystrophy, and others showed evidence of progression or worsening of secondary hyperparathyroidism.

The evolution of bone disease in these patients was not related to the duration or type of previous treatment for ESRD. It could be argued that patients in group II had undergone treatment with CAPD for a longer period of time than those in group I; however, the data in Figure 1 indicate that the serum alkaline phosphatase levels became divergent in the two groups even during the early period of treatment with CAPD. Also, the fraction of patients in the two groups with long-standing renal insufficiency before reaching end stage (i.e. those with dysplastic kidneys and polycystic kidneys) were similar in the two groups.

The adequate control of the radiological manifestations of secondary hyperparathyroidism in group I was associated with increments in the serum calcium level into the upper normal 


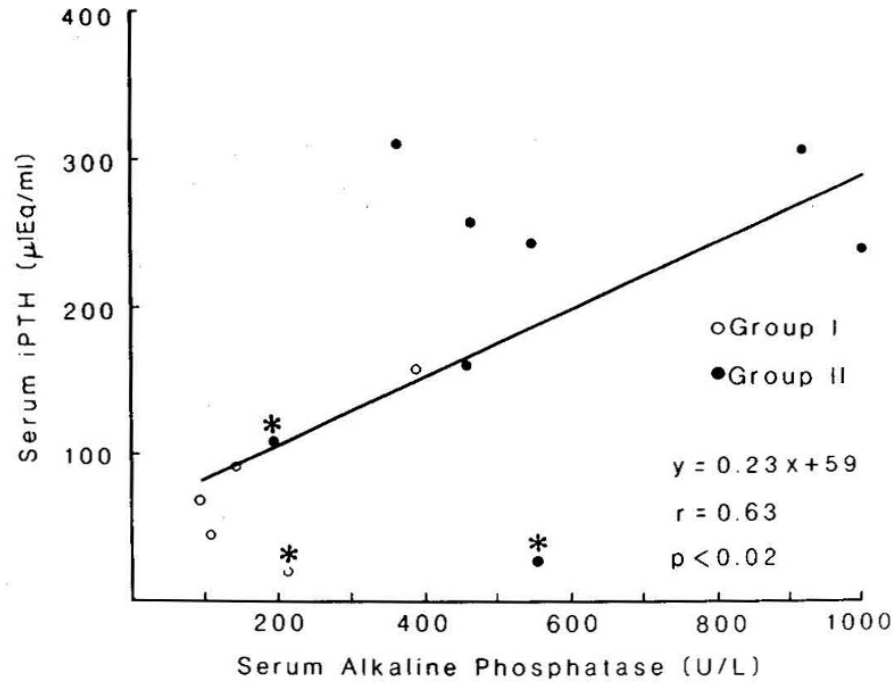

Fig. 4. Relationship betwen serum iPTH levels and alkaline phosphatase activity measured at the same time at the end of the period of observation. Patients in group I had lower levels of iPTH and lower alkaline phosphatase activity than those of group II. *, patients requiring parathyroidectomy prior to CAPD.

range or above normal values. Conversely, serum calcium levels increased significantly in only two patients in group II, and the serum calcium level was greater than $2.50 \mathrm{mmol} /$ liter in only three patients in this group at the end of the study period. Whether serum iPTH could be suppressed in group II if the serum calcium level was increased to the same values as those achieved in group I is not established by the present observations. Thus, it is possible that the serum calcium level may need to reach values above normal to achieve parathyroid suppression in uremic children. Such a phenomenon is consistent with the in vitro observation that there may be alterations in the calciumregulated inhibition of PTH release by the parathyroid cells obtained from uremic patients with secondary hyperparathyroidism (8). It has been shown that the "set point," or the calcium concentration at which iPTH secretion is inhibited by parathyroid cells, is usually higher than the level of suppression in normal parathyroid cells (7).

CAPD may have other effects on mineral metabolism which are different from those associated with hemodialysis. Delmez et al. (12) demonstrated that finite amounts of parathyroid hormone were present in the effluent dialysate of CAPD patients. It is not likely, however, that the amount is of major importance, since the serum iPTH did not fall markedly in most of their patients. During CAPD, various plasma proteins are lost into the dialysate $(2-4,17)$. This circumstance can lead to losses of the vitamin D-binding protein and 25 -hydroxyvitamin $\mathrm{D}(12,18)$. In patients undergoing CAPD, the serum level of $25-\mathrm{OHD}_{3}$ has been reported to be low or normal $(1,12,18,23,29)$. In this study, the serum 25-OHD levels were normal; this largely excludes the possibility that relative vitamin D deficiency may have contributed to the difference between groups I and II.

In the present study, the average net transfer of calcium into the dialysate did not differ from zero, although there was wide variation in individual patients. The presence of a significant net loss of calcium was dependent upon the magnitude of net peritoneal transfer of fluid from the patient during CAPD. In adult patients, the mean peritoneal calcium transfer during CAPD has been reported to be negative, neutral, or positive $(5,9,12,23$, 25 ), and the net transfer of calcium into the patients from dialysate was inversely related both to the serum calcium level and to the magnitude of net ultrafiltration (5).

Delmez et al. (12) reported greater negative calcium mass transfer when using the $4.25 \%$ in dialysate. The mean daily glucose concentration utilized in the dialysate was not different between the groups in the present study, making it unlikely that differences in ultrafiltration could account for the lower serum calcium in group II.

The dietary calcium intake varied from 450 to $1000 \mathrm{mg} /$ day in our patients. Since impaired calcium absorption exists in patients with renal failure, it is possible that this quantity is suboptimal. In adult patients undergoing CAPD, it has been suggested that oral supplements of calcium carbonate may have a beneficial effect on mineral metabolism and bone disease (13, $25,29)$. However, the concomitant administration of calcitriol and oral calcium supplements may increase the risk of hypercalcemia, and the use of the two together should be prescribed with caution.

In adults and children undergoing CAPD, serum phosphate concentrations have been reported to be easier to control than is the case during hemodialysis $(3,16,19)$. However, large amounts of aluminum hydroxide were necessary to maintain the serum phosphorus at or near the normal levels in the present group of patients. Accomplishing this was particularly difficult in the smaller children who did not easily accept the large amounts of phosphate binders. Calcitriol can increase intestinal absorption of phosphorus (6), and its use may be a factor contributing to hyperphosphatemia in these children. Chesney et al. (11) noted than an increase in the dosage of phosphate-binding agents was needed to maintain normal serum phosphorus levels in children with chronic renal failure treated with calcitriol. In the present study, the dose of phosphate-binding agents was similar in both groups.

The results of this retrospective study in children undergoing CAPD indicates that renal osteodystrophy may be potentially curable and/or preventable in children undergoing CAPD. They are comparable to those recently published by Hewitt $e$ t al. (20). It is possible that adjustment in the dosage of vitamin D sterols to maintain the serum calcium levels at the upper limits of normal while monitoring the serum alkaline phosphatase activity serially might result in improvement in a greater fraction of patients; indeed, a prospective trial to test this hypothesis is underway. Since normalization of the serum alkaline phosphatase activity is closely correlated with reduction in both serum iPTH levels and radiological evidence of bone disease, serial measurements of serum calcium levels and alkaline phosphatase activities may be used as parameters for the adjustment in the dosage of the calcium and vitamin D sterols prescribed.

\section{REFERENCES AND NOTES}

1. Aloni J, Chaimovitch C, Shany S 1982 Losses of 25-hydroxyvitamin D in peritoneal fluid: possible mechanism for bone disease in patients treated with chronic peritoneal dialysis (CAPD), Kidney Int 21:162 (abstr)

2. Balfe JW, Vigneux A, Willumsen J, Hardy BE 1981 The use of CAPD in the treatment of children with end-stage renal disease. Perit Dial Bull 1:35

3. Baum M, Powell D, Calvin S, McDavid T, McHenry K, Mar H, Potter D 1982 Continuous ambulatory peritoneal dialysis in children: comparison with hemodialysis. N Engl J Med 307:1537

4. Blumenkrantz MJ, Gahl GM, Kopple JD, Kamdar AV, Jones MR, Kessel M, Coburn JW 1981 Protein losses during peritoneal dialysis. Kidney Int 19:593

5. Blumenkrantz MJ, Kopple JD, Moran JK, Coburn JW 1982 Metabolic balance studies and dietary protein requirements in patients undergoing CAPD. Kidney Int 21:849

6. Brickman AS, Hartenbower DL, Norman AW, Coburn JW 1977 Actions of 1-hydroxyvitamin $D_{3}$ and 1,25-dihydroxyvitamin $D_{3}$ on mineral metabolism in man. I. Effects on net absorption of phosphorus. Am J Clin Nutr 30:1064

7. Brown E 1981 Set point for calcium: its role in normal and abnormal secretion. In: Cohn DV, Talmage RV, Matthews JL (eds) Hormone Control of Calcium Metabolism. Excerpta Medica, Amsterdam, p 35

8. Brown EM, Wilson RE, Eastman RC, Pallotta J, Marynick SP 1982 Abnormal regulation of parathyroid hormone release by calcium in secondary hyperparathyroidism due to chronic renal failure. J Clin Endocrinol Metab 54:172

9. Calderaro V, Khanna R, Oreopoulos DG, Quinton C, Meema EH, Carmichae D 1981 Renal osteodystrophy in patients on continuous ambulatory peritoneal dialysis (CAPD): a biochemical and radiological study. In: Moncrief JW, Popovich RP (eds) CAPD Update. Masson, New York pp 243-246

10. Cherian AG, Hill JG 1978 Age dependence of serum enzymatic activities (alkaline phosphatase, aspartate aminotransferase, and creatinine kinase) in healthy children and adolescents. Am J Clin Pathol 70:783

11. Chesney RW, Hamstra A, Jax DK, Mazess RB, Deluca HF 1980 Influence of 
long-term oral 1,25-dihydroxyvitamin D in childhood renal osteodystrophy. Contr Nephrol 18:55

12. Delmez JA, Slatopolsky E, Martin KJ, Gearing BN, Harter HR 1982 The effects of continuous ambulatory peritoneal dialysis on mineral metabolism. Kidney Int 21:862

13. Digenis G, Khanna R, Pierratos A, Mena HE, Rabinovich S, Petit J, Oreopoulos DG 1983 Renal osteodystrophy in patients maintained on CAPD for more than three years. Perit Dial Bull 2:81

14. Fine RN 1982 Peritoneal dialysis update. J Pediatr 100:1

15. Gertner JM, Tamborlane WV, Horst RL, Sherwin RS, Felig P, Genel M 1980 Mineral metabolism in diabetes mellitus: Changes accompanying treatment with a portable subcutaneous insulin infusion system. J Clin Endocrinol Metab 50:862

16. Gokal R, Ellis A, Ramos JM, Dewar J, Sweeting V, Ward MK, Kerr DNS 1981 Improvement in secondary hyperparathyroidism in patients on continuous ambulatory peritoneal dialysis (CAPD). In: Gahl GM, Kessel M, Nolph DK (eds) Advances in Peritoneal Dialysis. Excerpta Medica, Amsterdam, pp 461-466

17. Guillot M, Clermont MJ, Gagnadoux MF, Broyer M 1981 Nineteen months experience with continuous ambulatory peritoneal dialysis (CAPD) in children: main clinical and biological results. In: Gahl GM, Kessel M, Nolph $\mathrm{KD}$ (eds) Advances in Peritoneal Dialysis. Excerpta Medica, Amsterdam pp 203-207

18. Guillot M, Lavocat C, Garabedian M, Sachs C, Balsan S, Gagnadoux MF, Broyer M 1981 Evaluation of $25(\mathrm{OH}) \mathrm{D}$ loss in dialysate of children on continuous ambulatory peritoneal dialysis. Proc Eur Dial Transplant Assoc 18:290

19. Harrington JT 1982 Chronic ambulatory peritoneal dialysis. N Engl J Med 306:670

20. Hewitt IK, Stefanidis C, Reilly BJ, Kooh SW, Balfe JW 1983 Renal osteodystrophy in children undergoing continuous ambulatory peritoneal dialysis. $\mathrm{J}$ Pediatr 103:729

21. Horst RL, Littledike ET, Riley JL, Napoli JL 1981 Quantitation of vitamin D and its metabolites and their plasma concentrations in five species of animals.
Ann Biochem 116:189

22. Hruska KA, Kopelman R, Rutherford WE, Klahr S, Slatopolsky E 1975 Metabolism of immunoreactive parathyroid hormone in the dog. The role of the kidney and the effects of chronic renal disease. J Clin Invest 56:39

23. Kurtz SB, McCarthy JT, Kuman R 1981 Hypercalcemia in continuous ambulatory peritoneal dialysis (CAPD) patients: observations on parameters of calcium metabolism. In: Gahl GM, Kessel M, Nolph KD (eds) Advances in Peritoneal Dialysis. Excerpta Medica Amsterdam, pp 467-472

24. Oreopoulos DG, Robson M, Izatt S, Clayton S, DeVeber GA 1979 A simple and safe technique for continuous ambulatory peritoneal dialysis (CAPD). Am Soc Artif Intern Organs 24:484

25. Parker A, Nolph KD 1981 Magnesium and calcium mass transfer during continuous ambulatory peritoneal dialysis. Am Soc Artif Intern Organs 26:184

26. Salusky IB, Lucullo L, Nelson P, Fine RN 1982 Continuous ambulatory peritoneal dialysis in children. Ped Clin N Am 29:1005

27. Salusky IB, Kopple JD, Fine RN 1983 Continuous ambulatory peritoneal dialysis in pediatric patients-20 months experience. Kidney Int 24: S-101 (suppl 15)

28. Salusky IB, Nelson P, Fine RN 1984 Nutritional management of pediatric patients on dialysis. In: Nissensson A, Fine RN, Gentile D (eds) Clinical Dialysis. Appleton-Century-Crofts, New York (in press)

29. Tielemans C, Aubry C, Dratwa M 1981 The effects of continuous ambulatory peritoneal dialysis (CAPD) on renal osteodystrophy. In: Gahl GM, Kessel M, Nolph KD 1981 Advances in Peritoneal Dialysis. Excerpta Medica, Amsterdam, pp 455-460

30. This research was supported in part by United States Public Health Service Grant AM 14750, Veterans Administration Research Funds, and the Peter Boxenbaum Foundation.

31. The authors appreciate the technical assistance of J. Lee, R. Adachi, H. Dennin, S. Soghomonian, and A. Landsberg.

32. Requests for reprints should be addressed to Luc Paunier, M.D., Clinique de Pédiatrie, Hôpital Cantonal Universitaire, CH-1211 Geneva 4, Switzerland. 33. Received for publication February 3, 1984.

\title{
Cysteine Supplementation of Total Parenteral Nutrition: the Effect in Beagle Pups
}

\author{
MICHAEL H. MALLOY(28) AND DAVID K. RASSIN \\ Department of Pediatrics, The University of Texas Medical Branch, Galveston, Texas, USA
}

\section{Summary}

Total parenteral nutrition solutions supplemented with cysteine-HCl (S-TPN, $0.8 \mathrm{mmol} / \mathrm{kg} / \mathrm{day}$ ) were infused into beagle pups from day 10 of life to day $20(n=6)$. Another group of pups received unsupplemented TPN solutions (US-TPN) $(n=$ 6). Fluid, protein, and energy intake from nonprotein sources were similar in both groups. Data from these two groups were compared and similar measurements in normally suckled pups were also compared with the two TPN groups $(n=6)$.

There were significant differences in the rate of weight gain between the pups that received TPN and the pups that were suckled $(P<0.01)$. Weight gain, hepatic DNA and protein concentrations, and cerebral DNA and protein concentrations in the pups that received TPN supplemented with cysteine were not different from similar measurements in pups that received unsupplemented TPN. Plasma total cyst(e)ine (Cyst(e)ine refers to the mixture in any proportion of the sulfhydryl (cysteine) and the disulfide (cystine) forms of this compound) concentrations in the cysteine-supplemented pups $(7.9 \pm 1.2 \mu \mathrm{mol} / \mathrm{DL}, X \pm \mathrm{SD})$ were significantly greater than in the unsupplemented pups $(4.9 \pm 1.8$ $\mu \mathrm{mol} / \mathrm{DL})$. Hepatic glutathione concentrations in the supplemented pups (583 $\pm 85 \mu \mathrm{mol} / 100 \mathrm{~g}$ liver) were also significantly greater than in the unsupplemented pups $(392 \pm 113 \mu \mathrm{mol} / 100$ g liver). These data suggest that the supplementation of TPN solutions with cysteine, even in an animal enzymatically capable of cysteine synthesis, has significant effects on glutathione synthesis.

\section{Abbreviations}

TPN, total parenteral nutrition;

US-TPN, unsupplemented total parenteral nutrition;

S-TPN, cysteine-supplemented total parenteral nutrition

Cysteine is a sulfhydryl-containing compound that in adult man may be synthesized from methionine via the transsulfuration pathway (19). In the newborn, cysteine may be an essential amino acid (6). This hypothesis is based upon the observation that cystathionase activity, the rate-limiting enzyme for the synthesis of cysteine from methionine, is not present in the second 